\title{
Is the Price of Money Managers Too Low?*
}

\author{
Gur Huberman ${ }^{\dagger}$ \\ Columbia Business School
}

February 1, 2006

\begin{abstract}
Although established money managers operate in an environment which seems competitive, they also seem to be very profitable. The present value of the expected future profits from managing a collection of funds is equal to the value of the assets under management multiplied by the profit margin, assuming that the managed funds will remain in business forever, and that there will be zero asset flow into and out of the funds, zero excess returns net of trading costs, a fixed management fee proportional to the assets under management and a fixed profit margin for the management company. A profit margin of $30 \%$ seems empirically reasonable, but money management companies seem to trade at $2-4 \%$ of assets under management. Attempts to reconcile the two figures are not compelling, which is disturbing considering the centrality of the present value formula to finance and economics. Another computation suggests that holders of actively managed funds typically lose about $12 \%$ (18\%) of their assets if they hold the fund for 20 (30) years, as compared with a loss of less than $3 \%$ (5\%) for low-cost index fund investors for similar holding periods.
\end{abstract}

\footnotetext{
${ }^{*}$ An earlier version of this paper was titled What is the NPV of Expected Future Profits of Money Managers?

${ }^{\dagger}$ Conversations with numerous colleagues at Columbia and elsewhere were instrumental to the ideas summarized in this work. I am especially grateful to Mikhail Chernov, Charles Jacklin (Mellon Capital), Charles Jones, Thomas Miles, Rick Nelson (Ing Investment Management), Doron Nissim, Henri Pages, Ady Pauzner, Barbara Platzer, Stephen Ross, Michael Yates, Richard Zeckhauser, seminar participants at the Banque de France, Columbia, NYU, the Graduate center of CUNY, and the University of Texas at Austin. Jose Martinez provided insightful comments and excellent research assistance. Financial support from the Gamma Foundation is also gratefully acknowledged.
} 
There are hundreds of mutual fund families, barriers to enter the money management business seem low and little capital is tied up in that business, all of which suggest that the industry is competitive and that its producers should therefore have low if not zero profits. How does the market set the price of these expected future profits, i.e., how does the market price the equity of established money management firms?

Assuming that the annual rate of interest is fixed at $R$, consider a firm that manages a short term bond mutual fund and charges a fee at the end of each year equal to a fraction $c$ of the assets under management. Assuming that it initially manages $\$ A$, and that the clients neither add nor withdraw money from the fund, the stream of income that the management company will receive is: $A(1+R) c$ at the end of the first year, $A(1+R)^{2}(1-c) c$ at the end of the second year, $A(1+R)^{3}(1-c)^{2} c$ at the end of the third, etc. At the discount rate $R$, the present value of this stream is $A$ - the value of the assets under management. The management company uses its revenues to pay for asset gathering, retention and servicing, and portfolio management. It also pays income taxes on its profits. The rest goes to the management company's owners. Empirically reasonable estimates of the pre-tax and after-tax profit margins are $35 \%$ and $20 \%$, respectively. Such profitability seems difficult to reconcile with the industry being highly competitive.

This back-of-the-envelope calculation indicates that money management firms should be priced at between $20 \%$ and $35 \%$ of the assets under management. But they are priced at 1$4 \%$ of assets under management, a pricing range which applies to both private transactions, and to ten publicly traded money management firms.

It is tempting to explain away at least part of the discrepancy by invoking the risk that any given money manager may lose most or all of the assets under management for a variety of reasons, such as abysmal performance or serious legal problems. But the pricing formula also applies to the incumbent money managers collectively, not only to individual money managers. Therefore the validity of this explanation must rest on new entrants siphoning 
assets away from the incumbents or on another process by which investors will reduce their reliance on the traditional money management industry. (Such a process can be a transition to a continental-style banking sector or an environment in which money managers will be bypassed in favor of households' holding securities directly.)

Other explanations suggest that current fees and profit margins are not sustainable in the long run, and competition will shrink them. Since prices reflect expectations of future profits, these explanations cannot be ruled out, but they entail ominous predictions for the money management industry. And they beg the question, "Why hasn't competition eliminated these profits by now?"

Arbitrageurs who dismiss the ominous predictions will realize that the price discrepancy does not present easy profit-making opportunities. After all, only a fraction of the direct ownership stakes of money managers is traded regularly, and positions that attempt to exploit the price discrepancy will take years, perhaps decades to deliver profits. Indeed, even very patient investors cannot be certain of the profits. Ironically, it may be that the pricing of money management firms, which is determined primarily by institutional investors - i.e., money managers - may serve as a prime example of the limits of arbitrage.

Money managers' profits are derived from the fees they charge. In the absence of compelling evidence that active money managers typically deliver excess returns, their clients should pay close attention to these fees. Indeed, straightforward calculations show that typical fees and performance are likely to result in substantial wealth dissipation, especially for long term, buy-and-hold clients.

This paper elaborates on the present value calculation (Section 1), presents data on the actual pricing of money management firms and on their fees, profits and asset growth rates (Section 2), considers future parameter values which can be consistent with the market's pricing (Section 3), sketches how standard valuation would produce prices near the observed prices (Section 4), suggests that long term fund investors lose substantial fractions of their 
savings if they buy-and-hold typical under-performing funds (section 5), explains why returns data on publicly traded money managers are too noisy to reliably detect positive excess returns (Section 6), indicates why arbitrageurs with horizons shorter than a decade will be reluctant to attempt to exploit the mispricing (Section 7), points out that if money managers were operating in a truly competitive environment, they would not earn profits (Section 8), puts the results in the context of the most relevant papers (Section 9) and offers concluding remarks (Section 10).

\section{Present Value Calculations}

The discounted cash flow method requires the estimation of the expected future cash flows and of the rate at which they are to be discounted. It is common to decouple these estimations and it is almost always necessary to apply a good deal of judgement in estimating the expected cash flows and their appropriate discount rates. In contrast, discounting future fees of a money management firm is more tractable. This insight, and the calculation that follows, are based on Ross (1978), Brennan (1992), Ross (2001), Boudoukh et al (2003) and Cherkes (2004).

The following example captures the logic underlying the insight: Suppose that a year hence a money manager will charge a fee equal to $1 \%$ of the assets under management, and then liquidate the fund and return the assets to their owner. Assuming no excess return, the present value of the fee is $1 \%$ of the current assets under management.

The example illustrates that under simplifying assumptions, the rate at which the stream of future fees should be discounted is exactly equal to the (possibly uncertain) growth rate of these fees. Formally, consider the following set of assumptions:

1. During each time interval of length $\Delta t$ the fund continuously charges a fixed fraction $c \Delta t$ of its assets. 
2. No money flows into or out of the fund, with the exception of the management fees; all dividends and capital gains are reinvested in the fund.

3. The fund's excess return, after trading costs and before management, fees is zero.

Under these assumptions, the present value of future fees is equal to the value of the assets under management, regardless of the fee. The asset management firm retains (or passes to its owners) its profit, which is a fraction of the fee. Thus, the profit margin is important to determine a reasonable price for the asset management business. Focusing on established funds, with at least a few billion dollars under management, a pre-tax profit margin of $30 \%$ is conservative. Assuming such a margin is fixed forever and ignoring tax considerations, delivers a value of the management company equal to $30 \%$ of the assets' value. Assuming that the government collects about one third of the profits in taxes reduces the value of the management company to $20 \%$ of assets under management.

A fairly general calculation follows.

Suppose that the time- $t$ instantaneous annualized return net of trading costs is $r$, the comparable market return is $R$, the manager's fee is a fraction $c$ of the assets under management, the manager's profit margin is $m$, the inflow rate into the fund is $g$, and that the fund terminates at time $T$. Then for $t<T$, the time- $t$ assets under management $A(t)$ are

$$
A(t)=A(0) e^{(g+r-c) t} .
$$

The manager's net income from these assets between time $t$ and $t+\Delta t$ is

$$
I(t)=c m A(t) \Delta t .
$$

The present value of the stream of net income between time zero and $T$ is 


$$
\begin{aligned}
P V I & =\int_{0}^{T} e^{-R t} I(t) d t=A(0) c m \int_{0}^{T} e^{-(R-r+c-g) t} d t \\
& =\frac{A(0) c m}{R-r+c-g}\left[1-e^{-(R-r+c-g) T}\right] .
\end{aligned}
$$

Under the simplifying and apparently conservative assumptions that flows into and out of the money management firm are zero (i.e., $g=0$ ) and that the discount rate is equal to the return on the assets under management (i.e., $R=r$ ), the formula reduces to

$$
P V I=A(0) m\left[1-e^{-c T}\right]
$$

To interpret (3), divide the assets under management into two notional accounts: the first to be paid eventually to the clients who are the owners of the assets and the second to cover the fees to be paid to the manager. The present value of what the clients will receive at time $T$ is

$$
P V(A(t))=A(0) e^{-(R-r-g+c) T}
$$

whereas the present value of the fees is given in (3). The two present values add up to $A(0)$ if $g=0$ (no assets are added or withdrawn) and $R=r$ (zero excess performance). If the assets are held forever, i.e., $T=\infty$, the present value of the client's assets is zero. Although it makes no sense for any individual client to engage in this transaction, it may well be that, in aggregate, clients will behave in such a way that the asset manager will see no assets added or withdrawn over a very long time. Section 5 below offers calculations of clients' losses due to managers' fees over finite time periods.

When the time horizon is infinity $(T=\infty), g=0$ and $R=r, P V I$ is insensitive to the fee c. To understand this, note that increasing the fee from $c_{1}$ to $c_{2}$ will increase the manager's 
income in the short run at the expense of asset growth, and thereby at the expense of income in the long run. The two effects offset each other when the asset growth rate (gross of fees) is equal to the discount rate.

A typical pre-tax margin $m$ is higher than $30 \%$. If the life of the fund is open-ended, its management company should then trade at $20-30 \%$ of the assets under management, allowing for income taxes. But this is not the case.

\section{Prices, Profitability and Asset Flows}

The pricing formula is forward looking and there is no way to know either the future paths of the parameters that enter the formula or the market's expectations of these paths. (Or the market's expectation of the future paths of these expectations, which may be relevant to current pricing, etc.) The history of these paths and of the prices of money management firms can offer some indication for their future, and for beliefs about their future. Alas, the available historical records are not as comprehensive as one would like them to be.

Most money management firms are privately held or are wholly-owned subsidiaries of publicly held firms that have multiple lines of business, such as banks and insurance companies. Therefore it is impossible to obtain comprehensive data on market prices or the profitability of such enterprises. Nonetheless, some information is available. The equity of firms that concentrated in money management has traded publicly since at least 1974 . The equity of ten such firms traded publicly in 2002 .

\subsection{The Data}

The following procedure was used to identify publicly traded money managers. The first step was to search for all firms with the SIC codes 6211 (Security Brokers and Dealers), 6282 (Investment Advice, Portfolio Managers), 6722 (Management Investment Offices, Open-End; 
i.e., open-end funds), and 6799 (Other Investors). The next step was to match firms with these SIC codes to a list of mutual fund managers from the CRSP Mutual Fund database. The matching was done by name or a close variation of it. Firms that did not have mutual funds under management were discarded. The 2001, 2002 and 2003 annual reports of the remaining companies were read to exclude firms with substantial business outside investment management. The final step was to stipulate that reliable CRSP and COMPUSTAT data were available for the remaining firms.

Price data on the publicly traded money management firms are available from the University of Chicago's Center for Research in Security Prices (CRSP). COMPUSTAT has the income statements of these firms, and they were used here to study their profitability.

Additional information on prices is available from the mergers and acquisitions of money managers and from Wall Street analysts who also publish profitability and growth estimates. The Lehman Brothers report authored by Constant (2004) is an example. This information is consistent with the profit margins and pricing of the publicly traded money managers reported below.

Information on the asset flows for mutual funds and for families of funds are available from CRSP, starting with the years 1965 and 1993, respectively. Flows are not available for money managers in general. Data on mutual fund flows in the most recent decades should be interpreted with caution. Because these decades were very kind to the US mutual funds industry with the general disintermediation (which led to the emergence of money market funds and to funds holding asset-backed securities) and because of the early 1980s appearance and subsequent flourishing of $401(\mathrm{k})$ retirement plans, trends detected from these years should not be presumed to extend into the indefinite future.

The data are far from comprehensive, but the centrality of the present value formula to economics and the apparent discrepancy between the formula and the data call for a close scrutiny of the available data, coupled with the hope of obtaining better data in the future. 


\subsection{Prices of Publicly Traded Money Management Firms}

Table 1 summarizes the relevant data for the ten publicly traded money management firms at the end of 2002. Each firm managed tens of billions of dollars, and collectively they managed over $\$ 1.2$ trillion. (The mutual fund assets under their management totaled $\$ 653$ billion at the end of 2002. At that time mutual fund assets of all managers were $\$ 6.4$ trillion according to the 2003 Mutual Fund Fact Book issued by the Investment Company Institute.)

Not only did the sample firms have a substantial portion of the asset management market, it is also reassuring to note that the ratio of revenue to all assets under management is of the same order of magnitude as the fees money managers charge, averaging $.83 \%$. Thus, although the sample is not comprehensive, it is likely to be indicative of the industry.

The theory predicts that the ratio MV/AUM (enterprise value to assets under management) should fall between the ratio of (net income)/Rev (after-tax profit margin) and that of EBIT/Rev (before-tax operating margin). But the latter two ratios are between six and eleven times larger than MV/AUM, suggesting that the market seriously under-prices money management firms.

(The after tax margin takes into account the income taxes which the fund manager pays as well as the interest payments it makes on any debt it owes. Discounting the after-tax income stream is a complex exercise which should incorporate current and future tax rates as well as the fund manager's current and future leverage. Discounting future after-tax profits with the method sketched in the previous Section therefore offers a lower bound on the present value of the future profits.)

The range of ratios of market values to assets under management is similar in private transactions. Constant (2004) offers data on sixty-six acquisitions of asset managers that 


\begin{tabular}{|l|c|c|c|c|c|c|}
\hline Company & AUM $(\$ B)$ & REV/AUM & EBIT/REV & (N.I.)/Rev & Price/(N.I.) & MV/AUM \\
\hline Franklin & 248 & $1.04 \%$ & $25 \%$ & $17 \%$ & 19 & $3.49 \%$ \\
\hline Blackrock & 273 & $0.21 \%$ & $37 \%$ & $23 \%$ & 19 & $0.94 \%$ \\
\hline Eaton Vance & 56 & $0.94 \%$ & $35 \%$ & $23 \%$ & 16 & $3.81 \%$ \\
\hline Federated & 195 & $0.36 \%$ & $47 \%$ & $29 \%$ & 14 & $1.49 \%$ \\
\hline Gabelli & 21 & $1.02 \%$ & $44 \%$ & $25 \%$ & 17 & $5.13 \%$ \\
\hline Nuveen & 80 & $0.50 \%$ & $53 \%$ & $32 \%$ & 19 & $3.33 \%$ \\
\hline Janus & 138 & $0.83 \%$ & $32 \%$ & $7 \%$ & 34 & $2.72 \%$ \\
\hline Neuberger & 56 & $1.16 \%$ & $39 \%$ & $18 \%$ & 20 & $5.15 \%$ \\
\hline T. Rowe & 141 & $0.65 \%$ & $34 \%$ & $21 \%$ & 17 & $2.42 \%$ \\
\hline Waddell & 28 & $1.56 \%$ & $35 \%$ & $20 \%$ & 18 & $6.61 \%$ \\
\hline Average & $\mathbf{1 2 4}$ & $\mathbf{0 . 8 3 \%}$ & $\mathbf{3 8 \%}$ & $\mathbf{2 1 \%}$ & $\mathbf{1 9}$ & $\mathbf{3 . 5 1 \%}$ \\
\hline
\end{tabular}

Table 1: Publicly traded money management firms at the end of 2002: assets under management (AUM, dollars in billions), and the following ratios: Revenues to assets under management (Rev/AUM), operating profit margin (The ratio of EBIT - earnings before interest and taxes - to revenues), price to net income ratio, and the ratio of market value to assets under management (MV/AUM)

took place between March of 1997 and September of 2004. Figure 1 summarizes the distribution of the ratio $\mathrm{MV} / \mathrm{AUM}$ for these transactions. The mean (median) ratio was 3.2 $(2.5)$.

The price/earnings ratio is a more conventional measure of the reasonableness of the equity price, and Table 1 indicates that for money managers it is on average 19, well below the S\&P 500's P/E of 32 at the end of 2002. Constant (2004) provides income information on eighteen of the sixty-six acquired asset managers and reports that the mean (median) ratio of equity value to net income for these eighteen acquisitions was 26 (22.4). (In contrast, the $\mathrm{P} / \mathrm{E}$ ratio of the $\mathrm{S} \& \mathrm{P} 500$ without technology was near 17 at the time, and the $\mathrm{P} / \mathrm{E}$ ratio of the S\&P index of the financial sector was near 14.)

Theoretically, the $\mathrm{P} / \mathrm{E}$ ratio of the money managers should be much higher. Consider a hypothetical money manager with revenues equal to $.83 \%$ of assets under management and earnings (which equal to $21 \%$ of revenues) equal to $.83 \% x 21 \%=.18 \%$ of assets under management. If this management firm is priced at its theoretical lower (upper) bound of $21 \%(38 \%)$ of assets under management, then its theoretical $\mathrm{P} / \mathrm{E}$ ratio is $21 \% / .18 \%=121$ 


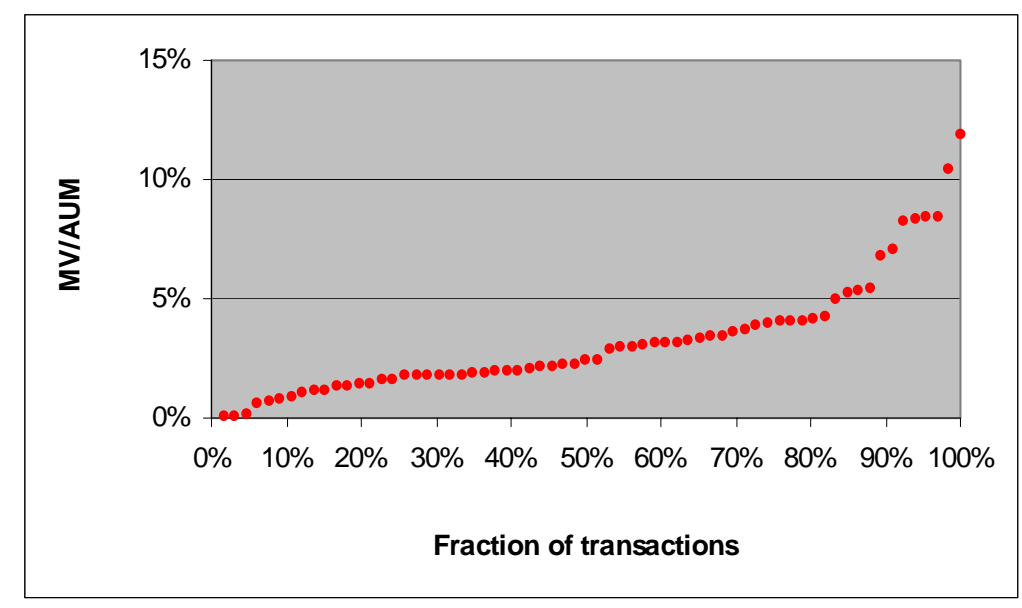

Figure 1: Cumulative distribution for the ratio of market value to assets under management in 66 acquisitions which took place between 1997 and 2004. Source: Lehamn Brothers research report by Constant (2004).

$(38 \% / .18 \%=215)$. Such outsized $\mathrm{P} / \mathrm{E}$ ratio bounds suggest that the gap between the theory and the data has to do with assumptions regarding parameter values in the very distant future.

Specifically, the theoretical price is based on a few assumptions regarding future conditions: that net asset flows will be zero, that fees and profitability levels will remain stable and that the funds will earn zero excess return before management fees are subtracted. History may offer some guidance regarding the reasonableness of these assumptions.

\subsection{The Power of Incumbency and Flow History}

The hiring and firing of institutional money managers is done by individuals who are seldom the sole direct beneficiaries of the managers' performance. These individuals often have a fiduciary duty to hire good managers and consequently they tend to hire managers with long and good track records, because they are less likely to be blamed if the performance of such managers disappoints. Such considerations give an edge to incumbents in the institutional money management arena. Name recognition as well as long and presumably good track 
records help incumbents at the retail level as well. These observations suggest that barring a structural shift in the money management business, incumbents as a whole are unlikely to consistently lose assets.

The valuation formulas in the previous Section may be suitable for established money managers with a good track record and substantial assets under management, but they are less suitable for new entrants. Therefore to assess the magnitude of the relevant asset growth rate $g$, the focus should be on the asset growth rates of larger and well established managers.

This study is about the value of asset gathering and retention by money managers, not about their ability to manage these assets. Comprehensive historical data on total assets managed by individual management firms are not available and the next best statistics to study are assets under management by families of mutual funds.

The proper units of analysis are probably fund families rather than individual funds, for several reasons. One, much of the branding, marketing and selling effort focuses on the fund family rather than on individual funds. Two, when a particular investment style or asset class becomes popular, the fund family is likely to respond by offering a new fund that appeals to current tastes. Three, it is easier to move money from one fund to another within a family than across families of funds. (This third observation is less relevant for institutional investors.)

Jointly, these considerations lead to the construction of Figure 2, which depicts the annual average asset growth rates of mutual fund families and of mutual funds in 1993-2002 for the largest families and the largest funds that were in business. Collectively, these managed $75 \%$ of the assets in mutual funds in 1993. (Changes in asset values through market appreciation and direct acquisition are excluded.)

A few observations emerge from Figure 2. First, the average annual asset growth rate of mutual fund families is $6 \%$, but it seems to decline over the 1993-2002 decade. Such a decline can be due to random fluctuations or due to a secular trend. With so few observations, it 


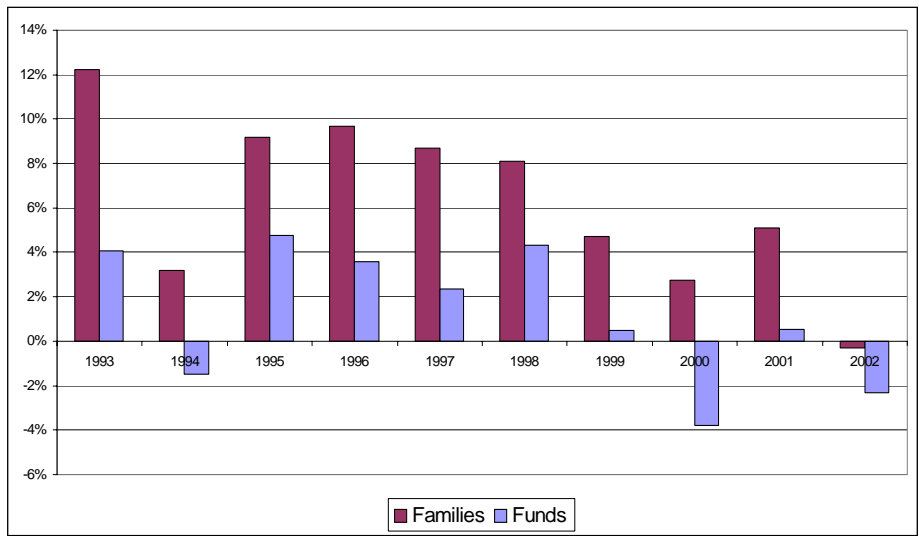

Figure 2: Annual asset flow rates for 1993-2002 to the largest families of mutual funds and to funds that existed in 1993. The flow rates to fund families (funds) are to the largest fund families (funds) that existed in 1993 and collectively managed 75\% of all fund assets in 1993.

is difficult to draw firm conclusions. Second, the asset growth rate of funds was consistently lower than that of fund families. This is probably the case because the growth rate of funds is for funds that existed in 1993, whereas the growth rate for fund families also reflects assets that went to funds which were established after 1993 by fund families that existed already in 1993.

The decade covered in Figure 2 saw the strong growth of 401(k) retirement plans at the expense of traditional defined benefit retirement plans. An inference of similar future growth rates is inappropriate. Indeed, such growth rates are not sustainable in the long run. But the experience of that decade, at least, does not suggest that incumbent money managers are likely to lose considerable assets in the future.

During the 1993-2002 decade, equity returns were high by historical standards. Although it is possible that assets will leave mutual funds if the market's returns are low, the empirical work of Warther (1995) suggests otherwise. He writes: "There is no evidence that aggregate fund flows are positively related to past returns in weekly, monthly, quarterly, or yearly data, nor is there evidence for the widely held belief that investors move money into funds in repose to high returns. This contrasts with the micro studies that find a positive relation between 
returns and subsequent flows at the individual fund level. In fact, there is evidence that flows are negatively related to past returns in monthly data; mutual fund investors appear to be somewhat contrarian."

The history of asset growth therefore need not represent the future growth or the expected future growth. The recent proliferation of hedge funds may be a harbinger of a trend not only of asset growth in the hedge fund industry, but also of such growth at the expense of traditional money managers. Indeed, controlling for asset size, ownership of at least some hedge funds has been priced much higher than ownership of a traditional money management business. For instance, the 9/26/2004 issue of the Wall Street Journal reported that JP Morgan acquired a stake in the $\$ 7$ billion hedge fund Highbridge in a transaction that valued the fund at $\$ 1$ billion, i.e. at about $15 \%$ of assets under management. The pricing model in this paper does not cover hedge funds which earn performance-based fees. (Goetzmann, Ingersoll and Ross, 2003, offer a pricing theory for hedge funds.) The assets managed by hedge funds are a small fraction of the total assets under management. In fact, the very entrepreneurial nature of hedge funds, coupled with their fee structure, suggests limitations on their growth. Be that as it may, one cannot rule out the possibility that assets will migrate from traditional managers to hedge funds, thereby shrinking the assets managed by traditional managers.

With technological and regulatory changes, the financial industry has seen considerable disintermediation in the last decades. It is possible that the next phase in the disintermediation will involve more households holding more securities directly, thereby diminishing the assets managed by the traditional asset managers.

Another potential source of the shrinkage of assets under management is net dissavings by the clients. For instance, rather than reinvest distributed dividends, they can choose to use them to fund consumption. Such a behavioral change cannot be ruled out, but it seems unlikely to take hold as long as the population and per capita wealth grow. 


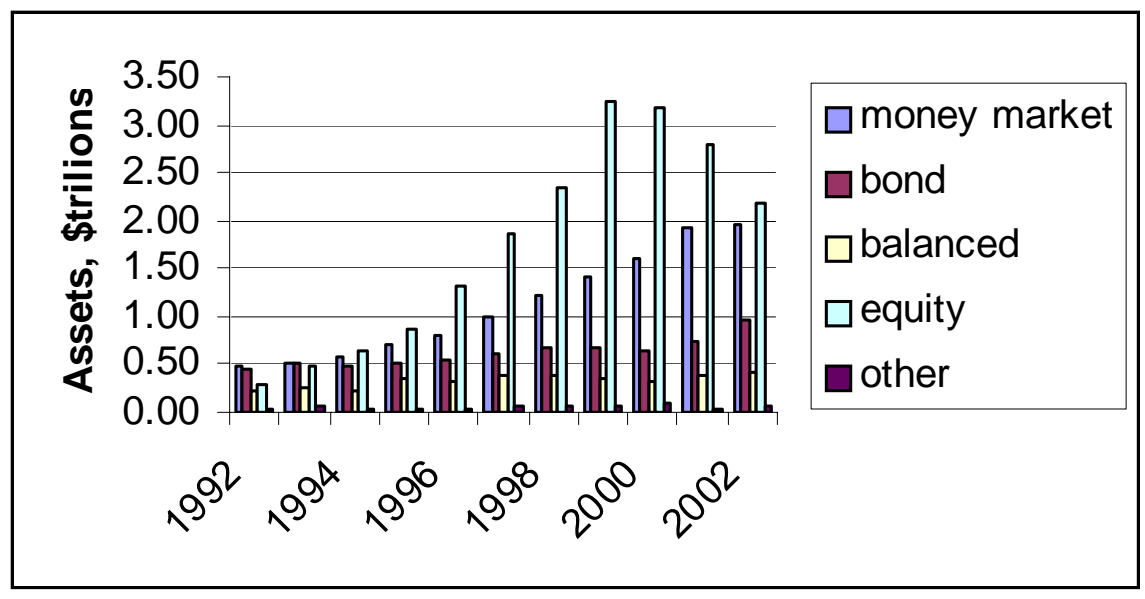

Figure 3: Total assets in mutual funds, by category

It is just as easy to come up with scenarios in which assets under management grow until almost all assets are eventually managed by traditional asset managers. Therefore, setting $g=0$ in $(3)$ seems reasonable, and perhaps even conservative.

\subsection{Expense Ratio and Margin History}

Mutual funds fall into a few broad categories; Figure 3 provides the historical assets under management of these categories. Most of the $\$ 6.4$ trillion in mutual funds in 2002 were in equity funds (39\% of the total) and in money market funds (35\%). Attempts to discern secular trends in fee size should focus on these two categories, because they cover the bulk of the assets under management.

CRSP gives the actual expense ratio of mutual funds. Figure 4 depicts the history of these asset-weighted ratios for the five fund categories. It suggests that fees have not shown a tendency to diminish over time.

The expenses (or fees) for the funds' investors are the revenues that appear on the income statements of the fund managers. Costs (including portfolio management, marketing and sales expenses) are paid out of these fees. Fund managers' operating income is the difference 


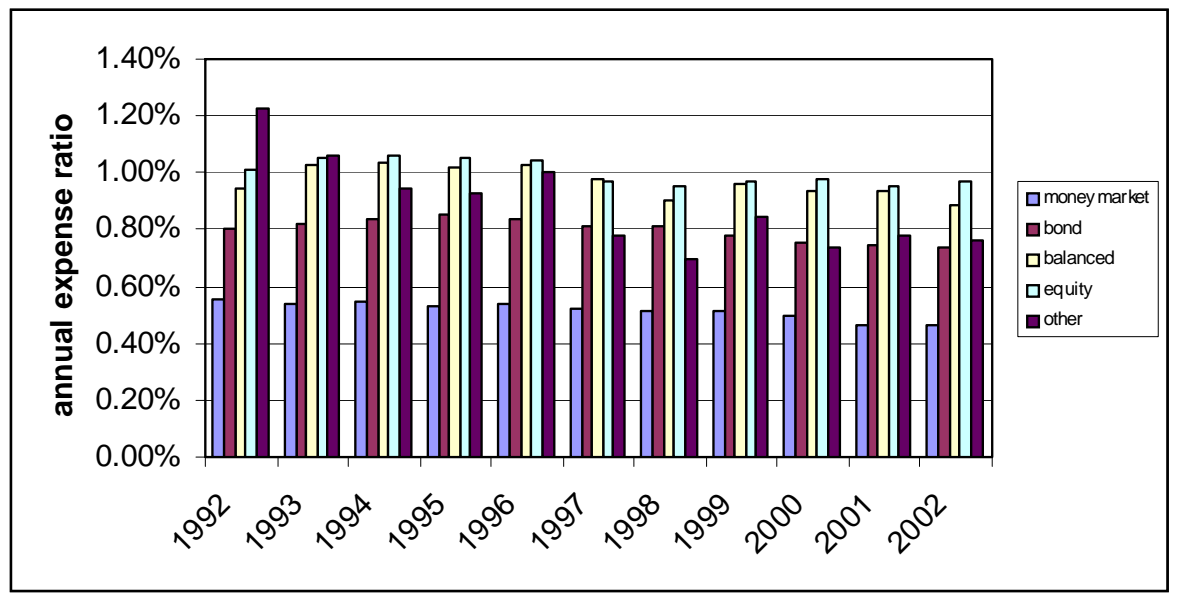

Figure 4: Average annual expense ratios for various mutual fund categories, 1992-2002.

between their revenues and costs and it is commonly referred to as EBIT or "earnings before interest and income taxes." The ratio EBIT/Revenues is the (before tax) profit margin or profitability.

Data on the revenues and profit margins of money managers are available only for standalone, publicly traded money managers. Figure 5 depicts the number of publicly traded money managers and their average profit margins from 1974 to 2002 . The number of publicly traded money managers is small, but it has been increasing over the years. (The small number of publicly traded money managers does not imply that most managed money is managed by privately held businesses. Rather, a substantial fraction of managed assets are in fact managed by subsidiaries of publicly held firms, such as banks.) Figure 5 also suggests that before- and after-tax profit margins move in tandem and that they seem to have increased substantially in the past three decades. This increase may have been an industry-wide trend. A narrower interpretation associates the increase in profitability with the selection from the whole group of money managers into the small subset of publicly traded managers. 


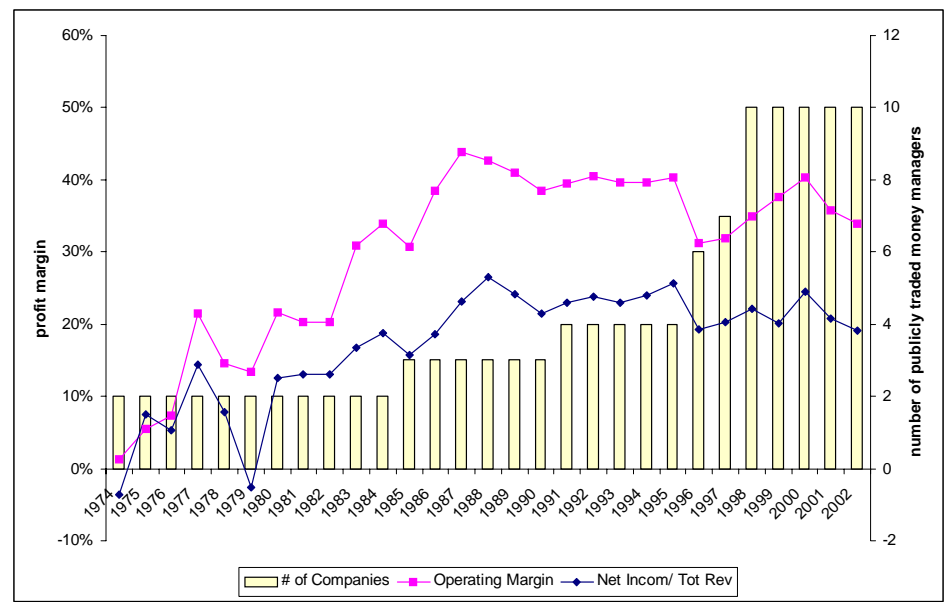

Figure 5: The number of publicly traded money managers, their average operating margins and the average ratios of their net income to revenue, 1974-2002.

\subsection{Summary}

Assuming that past flows, fees and profit margins will persist in the indefinite future, prices of money managers seem to be about $1 / 5$ to $1 / 10$ of where they should be theoretically. If the market cannot be that wrong, the implication is that, in sharp contrast with the history of the recent decades, the future will see some combination of assets flowing out of the incumbent managers and their profitability considerably shrinking.

\section{Rationalizing the Prices of Asset Managers}

Substituting historical parameter values in the present value formula yields prices which are much higher than those observed. This section engages in the reverse exercise, namely it reconsiders equations (1) - (4) and identifies parameter configurations under which the price is right.

It is possible that the assets' return $r$ is lower than the risk-adjusted discount rate $R$ because turnover, and the transaction costs it entails, reduces the fund's returns. For an equity fund with $100 \%$ annual turnover and trading costs of $.60 \%$ for the combined purchase 
of a security and a sale of another, it is reasonable to assume that the difference $R-r=.60 \%$. (Note, however, that assuming positivity of $R-r$ on average for the incumbent money managers means that, on average, their risk-adjusted returns are negative at $r-R$. Negativity of the projected returns raises other issues, such as what the economic role of asset managers is, and what their clients' expectations are.)

With the normalization $A(0)=1$ and assuming $T=\infty$, rewrite (3) as

$$
g=R-r+c-c \frac{m}{P V I}
$$

With annual trading costs at .6\% and fund fees at .75\%, the equation translates to

$$
g=.6 \%+.75 \%\left(1-\frac{m}{P V I}\right)
$$

which implies, for instance, that the growth rate necessary to rationalize, say $m / P V I=$ 11 , is $g=-6.9 \%$. An annual shrinkage rate of $6.9 \%$ means that five (ten) years from now the incumbent managers will lose about 30\% (50\%) of the assets they currently manage, with asset size adjusted for the returns. A more modest $m / P V I=6$ results in $g=-1.65 \%$, suggesting that five (ten) years from now the incumbent managers will lose about $8 \%(15 \%)$ of the assets they currently manage, with asset size adjusted for the returns.

Studying mutual funds during the period 1985 - 1994, Gruber (1996) offers another set of numbers from which $g$ can be calibrated. He reports: "[M]utual funds underperform an appropriately weighted average of the indices by about 65 basis points per year. Expense ratios for my sample averaged 113 basis points per year." Substitute $R-r+c=.65 \%$ and $c=1.13 \%$ into (6), and assume say $m / P V I=11$, to obtain $g=-11.78 \%$. Applying Gruber's numbers to $m / P V I=6$ results in $g=-5 \%$.

Money managers may be less profitable in the future. Suppose that the margin at time t, $m(t)$, satisfies 


$$
m(t)=m_{0} e^{-\mu t}+m_{\infty}\left(1-e^{-\mu t}\right)
$$

indicating an exponential decay of the margin from the current $m_{0}$ to the eventual margin $m_{\infty}$. Substitution of (7) into (2), reevaluation of (3), and again setting $A(0)=1$ and $T=\infty$, results in

$$
\frac{P V I}{m_{0}}=\frac{c \frac{m_{\infty}}{m_{0}}}{R-r+c-g}+\frac{c\left(1-\frac{m_{\infty}}{m_{0}}\right)}{R-r+c-g+\mu} .
$$

Returning to the base case $R-r=g=0$, the equation reduces to

$$
\frac{P V I}{m_{0}}=\frac{m_{\infty}}{m_{0}}+\frac{c\left(1-\frac{m_{\infty}}{m_{0}}\right)}{c+\mu},
$$

indicating that a low valuation $P V I$ relative to current profit margin $m_{0}$ can be rationalized by a low eventual profit margin $m_{\infty}$ and a high convergence rate to it, $\mu$. But for all convergence rates $\mu, P V I / m_{0}>m_{\infty} / m_{0}$, implying (within this base case) that to rationalize a price which is $1 / 6$ of the after-tax profit margin, profit margin will have to drop to less than $1 / 6$ of their current levels, e.g., from $21 \%$ to $3.5 \%$.

To pursue this example further, assume that the fee rate $c=.75 \%$, current after-tax profit margin $m_{0}=21 \%$, and $P V I=5 \%$ (a generous assumption!). Equation (9) is satisfied, e.g., with an eventual profit margin $m_{\infty}=2.1 \%$ and an annual convergence rate slightly greater than $\mu=4 \%$. Assuming that the eventual profit margin will be zero $\left(m_{\infty}=0\right)$ and maintaining all the assumptions delivers $\mu=3.15 \%$.

The parameter values entertained in this section can emerge if the industry becomes very competitive. But so far competition has not eliminated money managers' profits. Moreover, recalling the economies of scale associated with money management, it is reasonable to assume that assets will increase at the rate of the underlying returns, whereas costs will rise more modestly. If this is the case, then profit margins will rise, not shrink. 
In summary, it seems unlikely that some expectation of future parameter paths is reasonable in light of both the current prices of money managers and the history of these parameters and prices. But this is also a matter of judgement.

\section{How Can It Be? Standard Present Value Analysis of a Money Manager's Expected Free Cash Flows}

The standard business valuation approach entails the estimation of the business' expected free cash flows and the risk of these flows, and then the adding up of the risk-adjusted present values of these expected cash flows. Although conceptually simple, the application of the procedure is complex and requires a good deal of judgement. Moreover, the analysis often reduces the cash flows associated with the distant horizon to a single, terminal value. (Higgins, 2004, offers a summary of the more popular valuation techniques.)

An analyst report issued by the banking firm A. G. Edwards summarizes its valuation methodology, which is quite typical of the industry, as follows: "Our primary valuation determinants for our universe [of money managers] are individual discounted cash flow models. In our DCF models, we typically forecast annual free cash flows for a 10-year period and then assume that the businesses are mature and grow at a rate close to that of the real economy. Our estimates of free cash flow are discounted at an appropriate risk-adjusted discount rate specific to the individual companies. Often, we look at other metrics, most notably price to earnings, PEG, relative $\mathrm{P} / \mathrm{Es}$ and price to revenue ratios, for a more complete picture of where a company is trading in relation to both its peers and its historical averages. Two of the primary risks to most of our universe would be a general economic slow down or a problematic merger." (Hopson et al, 2004, page 35).

Consider a typical valuation exercise. It takes the revenues to be $.83 \%$ of the assets under management and the net income - which is the free cash flow in this simple case - 
to be $.21 \%$ of assets under management. The important growth assumption is that assets will grow annually by $15 \%$ on average through a combination of net new flows and market returns. Taking the discount rate to be $13 \%$ per annum, the present value of the first ten years' net income is $1.4 \%$ of the initial assets under management.

With an annual asset growth rate of $15 \%$, the expected assets under management at the end of the 10th year are 3.5 times the initial level of assets under management. At this point the valuation exercise calls for a valuation of the business not as it currently is, but as it is projected to be ten years hence. One way to proceed is to assume that it will be priced ten years from now at, say, 3.5\% of assets under management. Discounting this valuation to the present at $13 \%$ per annum delivers a present value of the 10 -years-hence value equal to $3.6 \%$ of current assets under management. Together with the $1.4 \%$ NPV of the first ten years' expected cash flows, this delivers a valuation of $5 \%$ of assets under management.

Other approaches to the calculation of the terminal value are also possible. For instance, if the terminal value is 19 times the tenth year's net income, then its present value is $3.2 \%$ of the current assets under management. Naturally, higher discount rates and lower growth rates will deliver lower valuations.

The sketched application of the DCF method indicates that this technique requires fairly arbitrary assumptions, e.g., on future revenue growth rates, risk adjustment to the discount rate, and on long term market pricing multiples. When making these standard assumptions, the technique is unlikely to uncover a conflict with the market prices of money managers.

\section{The Perspective of the Mutual Fund Holder}

Equation (5) with $g=0$ allows for the computation of the fraction of assets dissipated away from the retail investor for various holding periods, assuming all dividends are reinvested. Two examples are summarized in Figure 6. The first uses Gruber's (1996) estimates of annual fee and excess performance at $1.13 \%$ and $-.65 \%$, respectively. The second is for an 


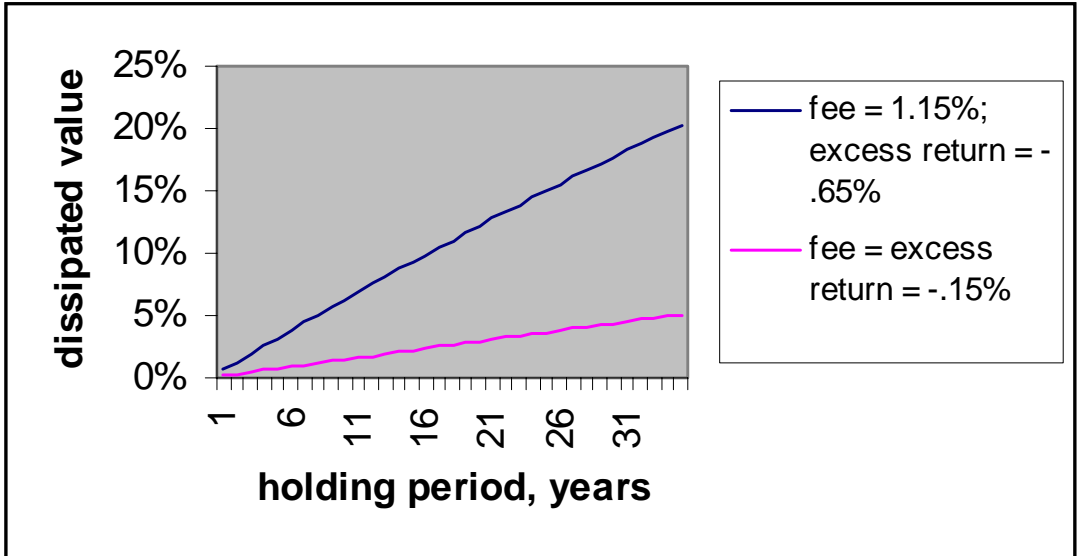

Figure 6: Fraction of wealth lost by a fund holder, relative to investing directly in an index.

index fund that charges $.15 \%$ annually. Consistent with its fee, the excess performance of the index fund is exactly $-.15 \%$.

A holding period of two to three decades is quite reasonable, especially for participants in 401(k) retirement plans. A fund to which the Gruber numbers apply will dissipate $12.2 \%$ of an investor's wealth if he holds it for 20 years and $17.7 \%$ of his wealth if he holds it for 30 years. In contrast, a .15\%-a-year index fund will dissipate $3 \%$ of the wealth of an investor who holds it for 20 years and $4.4 \%$ of his wealth if he holds it for 30 .

The amount of wealth which investors in active funds dissipate seems large, especially since low-cost index funds are available to fund investors outside 401(k) plans, as well as to many participants in such plans. One might wonder what it is exactly that investors in active funds think they receive from their fund managers and what useful economic role the funds play. Moreover, Figure 6 also suggests that 401(k) plan sponsors who fail to include low-cost index funds among their offered funds are doing a disservice to the participants. 


\section{Mispricing as Excess Returns}

Equity returns are approximately intertemporally independent and identically distributed. It is therefore statistically convenient to study them rather than price levels in order to detect mispricing. This approach is fruitful when the returns series is long or the returns are sufficiently positive relative to the returns' variability. Unfortunately, this is not the case here.

To contemplate such a study, consider the returns to holding the stock of a hypothetical firm which manages a single, all-equity fund. Further, assume that the net asset flow into the fund is zero, that the fund's return matches the return of the market $r$ (which implies that excess returns are exactly offset by trading costs), and that the stock of the management firm trades and will trade at a fraction $p$ of assets under management. Suppose further that the fund's annual fee is a fraction $c$ of the assets under management, the profit margin is $m$, that at the end of the year the fees are charged and all profits are distributed as dividends to the holders of the management firm's stock.

The one-year capital gain to holding the manager's stock is $(1+r)(1-c) p / p-1$, and the end-of year dividend yield is $(1+r) \mathrm{cm} / p$. The total one-year return is $(1+r)(1+c(m / p-$ 1)) -1 , which implies an excess return of approximately $c(m / p-1)$. With $c=.75 \%$ and $m / p=11$, this is an annual excess return of $7.5 \%$. With $m / p=6$, the implied annual excess return is $3.75 \%$.

The calculated hypothetical excess returns entail considerable uncertainty. Any specific fund family is more complex than a manager of a pure, simple stock fund which pays out all its profits as dividends. With fund families, often some of the profits are retained, usually to finance acquisitions. Fund families also manage varieties of funds, each with its own fee and profit structure. Fund families merge with or acquire other fund families, as well as add to their offerings over time. Clients move money across funds within fund families, and across fund families, as well as add or withdraw money altogether. Profit margins and trading 
costs are unstable over time. Moreover, the market's perceptions of the future evolution of these parameters changes, and changes in these perceptions affect the stock prices of money managers.

To set up a statistical model of the excess returns to holding stocks of money managers, one would first need to estimate the expected excess returns and then test if they are statistically positive. To do this, one would need to specify benchmark returns, or at least estimate them. When the money manager's only business is a single fund with a single asset class, the task is relatively easy. The benchmark return is the return on that asset class. In contrast, most fund families manage funds consisting of assets from more than one class. And the relative weights of the different classes change. Thus, the benchmark selection is difficult, and mistakes and compromises in the estimation of the correct benchmark returns will lead to biases and errors in the estimation of the excess returns on the stocks of the money managers.

In summary, the small number of publicly traded money managers, their heterogeneity and the short period for which they have been publicly held, all suggest that the excess returns of holding a portfolio of these money managers is statistically indistinguishable from zero.

\section{Had We But World Enough, and Time}

A mispricing suggests profit opportunities. What does it take to exploit the gap between the theoretical and actual pricing of money managers? It takes time, and resources dedicated to long-term arbitrage are limited. (See Shleifer and Summers, 1990, and Shleifer and Vishny, 1997.)

There are four categories of arbitrage opportunities. In the first and simplest, a trader opens a position and leaves it intact until he closes it on a certain future date which is known at the time the position is opened. Counter-party credit risk aside, a violation of the covered 
interest rate parity lends itself to such a trade. Violation of the put call parity is another example.

The second category requires the trader to adjust his position periodically, but the position's closing is still on a future date which he knows when opening it. Reliance on dynamic trading requires the trader to count on market liquidity during the execution of the trade. A violation of the Black-Scholes options pricing formula lends itself to such a trade.

In the third category, a particular position is very likely to deliver positive profits by a certain date, but the profits are not assured. For instance, consider the case of firms A and $\mathrm{B}$ agreeing to merge by a certain date with the shares exchanged 1 for 1 with the shares of the merged firm. A few conditions may still have to be met before the merger concludes, but the date of its contingent conclusion is known. In this case the shares of firms A and B should trade close to parity, and a deviation from equal price of the shares would call for buying the cheap and shorting the rich by those who believe that the merger will likely take place at the announced terms.

The fourth category of a pricing discrepancy exploitation has no certain closing date, but relies either on an extremely long holding period or on the market's general tendency to converge eventually to some reasonable pricing. The apparent mispricing of money managers may offer an arbitrage opportunity of this fourth category. An assessment of an attempt to exploit the price discrepancy calls for an analysis of the temporal dimension of the price discrepancy.

Consider a finite horizon model in which the asset manager ceases operations and returns the assets to its clients $T$ years from now. How many years of operations will it take to render the present value of the income from ownership equal to the initial investment $p$ in the money management business under the benchmark case (i.e., asset growth rate $g=0$ and excess return $r-R=0)$ ?

Figure 7 depicts the solutions $T$ to equation (4) under various parameter configurations. 


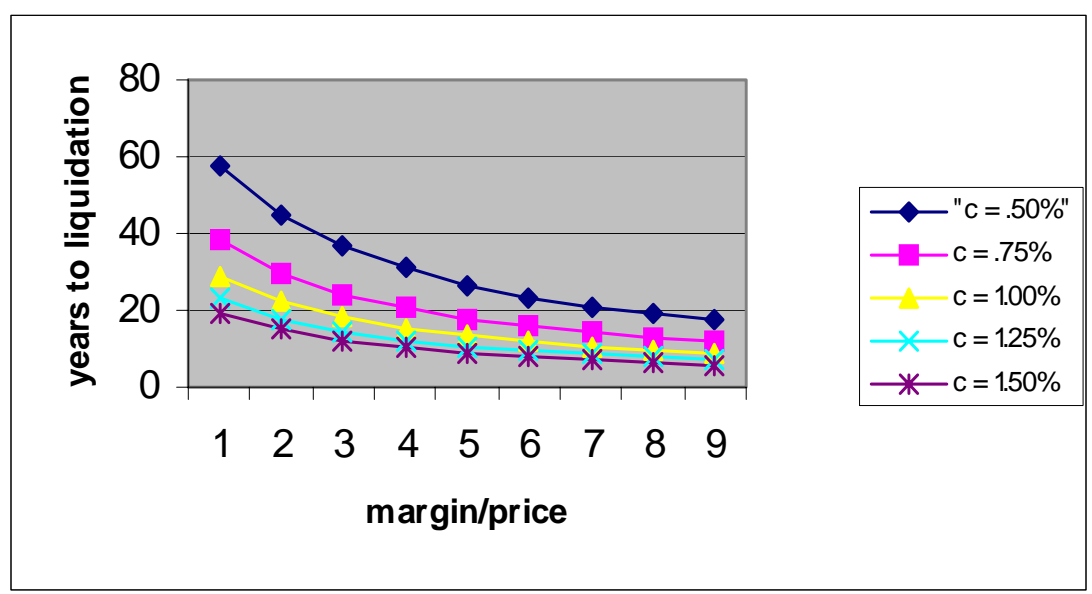

Figure 7: Given a margin/price and fee of c, the number of years till the money management business is expected to liquidate. Price is per dollar of assets under management.

Approximately, $T=1 / c(m / p)$. Note that under reasonable parameter configurations the liquidation period can exceed two decades. For instance, if the fee $c=.75 \%$ and the margin/price ratio $m / p=6$, the liquidation period is 24 years.

An alternative way to appreciate the numbers is to think of a potential buyer of the equity of the money manager who believes that current parameters and the fund itself will survive forever. Such a buyer, if his holding period of the equity were infinity, would say that he is buying equity in the money manager at a fraction of its fundamental value equal to $p / m$. But what about a potential buyer who plans on a holding period of just $t$ years? The computation of his discount requires an assumption about the resale price of these shares. Assuming that the resale price/margin ratio will be equal to the purchase price/margin ratio, the present value of his income from dividends and the ultimate resale of the shares is $m\left(1-e^{-c t}\right)+p e^{-c t}$. Purchasing this income at a price $p$, he receives a discount $D$, which solves the equation $p=(1-D)\left(m\left(1-e^{-c t}\right)+p e^{-c t}\right)$. Figure 8 depicts the discount $\mathrm{D}$ for various holding periods and margin/price ratios. Considering that horizons of arbitrageurs are usually shorter than five years, these discounts seem small - no greater than $30 \%$ for holding periods of five years or less. 


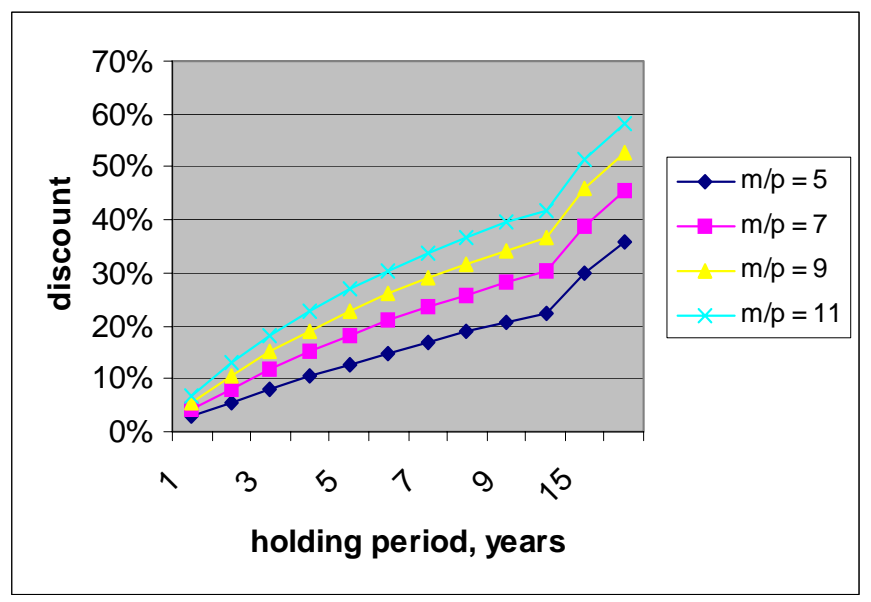

Figure 8: The implied discount on the cost of a money manager, assuming resale at the end of a given holding period at the same margin/price ratio as that prevailing at the purchase time.

The profits implied in Figures 7 and 8 require holding the position for a few years. Moreover, they are highly uncertain because for any given publicly held money manager, or even a set of them, the assets they manage, as well as their profits, can shrink. In addition, there is no guarantee that they will pass their earnings to their shareholders.

An arbitrageur will be tempted to exploit mispricing if he expects that market forces will cause the mispricing to disappear. This will happen if other market participants buy shares of money managers in recognition of the value locked in these shares. But as long as much of the market applies DCF techniques as illustrated in Section 4, the arbitrageur will not expect these prices to appreciate considerably, and therefore will not buy shares of money managers. Such passivity of the arbitrageur community as a whole will leave prices at their current level, assigning little value to streams of benefits which are likely to accrue in the very distant future. The pricing of money managers may therefore reflect hyperbolic discounting at the market level. (Laibson, 1997, and Stortz, 1956, are standard references for hyperbolic discounting by individuals.)

In his discussion of the state of long-run expectations, Keynes (1936) observed: "[L]ife is 
not long enough; - human nature desires quick results, there is a particular zest in making money quickly, and remoter gains are discounted by the average man at a very high rate." (Italics added.)

Keynes (1936) also asserted that prices could deviate from their fundamental values due to the animal spirits of humans who trade in the financial market. He did not specify the direction of the mispricing. Adam Smith (1776) had a similar view: "The value of a share in a joint stock is always the price which it will bring in the market; and this may be either greater or less, in any proportion, than the sum which its owner stands credited for in the stock of the company." And more recently, Black (1986) asserted, "we might define an efficient market as one in which price is within a factor of 2 of value... The factor 2 is arbitrary, of course... By this definition, I think almost all markets are efficient almost all the time. 'Almost all' means at least 90\%."

Miller (1977) argued that short selling constraints precluded the views of the most pessimistic market participants from being reflected in prices and that asset prices could therefore exceed their fundamental values, i.e., the present value of the dividends they were expected to generate in the future. Harrison and Kreps (1978) offered a formal dynamic model of investor disagreement and short sale constraints causing mispricing. (Scheinkman and Xiong, 2003, were a recent addition to that literature.) These models all share a common theme: assets may be over-priced. In contrast, the present paper offers evidence which suggests that stocks of money managers are persistently under-priced.

It is often thought that it is institutional investors (i.e., money managers) who are the price-setting marginal investors. In fact, if the proverbial marginal investors apply the dividend discount method as sketched in Section 4, they will not conclude that current prices are very wrong. Thus, ironically, a mispricing can persist in the money managers' own backyard - the pricing of their own businesses. 


\section{Profits and Competition}

The profitability of money managers plays a central role in this paper. Profits of money managers are relatively easy to estimate because money managers' pre-tax profits are their operating profits, with there being no need to adjust for the cost of capital (which is not tied up in the business).

To illustrate the size of the capital necessary to set up a money management business, note the following statement from a report by the banking firm A. G. Edwards: "LSV was established in 1994 by three college professors who had developed a value-oriented, quantitative model. In seeking a financial partner, they found [SEI Investment], who invested $\$ 1$ million (51\% ownership) in LSV asset management... The investment turned out to be a great one, with LSV's assets under management now total $\$ 25$ billion and we estimate that it will generate $\$ 44.7$ million in earnings for [SEI Investment] in 2004." (Hopson and Mason, 2004, page 3.)

With thousands of funds and hundreds of fund families, the money management industry should be highly competitive. (Khorana and Servaes, 2003, report there to be 404 fund families in 1989, 479 in 1994 and 525 in 1998.) But it also seems highly profitable. How does one reconcile the industry's apparent competitiveness with its profitability?

The issues at hand are somewhat different for retail and institutional products. At the retail level, customers may pay little attention to fees and to fee differences across funds because these fees seem small. It may even be the case that cutting the fee to bolster performance is a money-losing proposition for the money manager. But at least formally, each mutual fund has trustees who are supposed to look after the interests of those whose assets are managed by the fund, not the interests of the firm that manages the assets. Why do these trustees not cut the fees and thereby also the managers' profits? Probably because,

although formally the trustees are accountable to the funds' clients (i.e., those whose money is managed), in practice they owe their positions to the fund managers, and they tend to 
act in accordance with the managers' interests. As Kim (1998) suggests, the law does not seem to get in the way of such behavior: "The great majority of cases involving challenges to management fees have been settled. Only a few such cases have been tried on their merits under section 36(b) [of the Investment Company Act of 1940]. Notably, plaintiffs have never brought a successful action against a fund's directors or adviser for excessive management fees." (Kim 1998, pp. 490-91; footnotes omitted.)

In defined contribution retirement plans such as $401(\mathrm{k}) \mathrm{s}$, plan sponsors contract with fund families to offer their funds to participants. Incentives for individuals to participate are strong, thanks to their preferential income tax treatment and often also to the sponsor's matching contributions. Participants are captive clients of the offered funds. One might think that plan sponsors would negotiate the fees down to (almost) eliminate the profits of the money managers, who presumably compete to offer their services, but the fees charged to fund holders in 401(k) plans are often the same as those charged to other retail customers.

The overlooking of the seemingly small fees by retail customers and the excessive attention these customers pay to fund brokers and financial advisors offers at least a partial explanation of the profitability of funds that cater specifically to retail customers. But such arguments should be less relevant for institutional money management, which is often performed by the same organizations that manage money for retail customers. Presumably institutional clients are savvier than retail customers and, negotiating from a strong position, can haggle the management fees down to their competitive levels, i.e., to the point at which institutional money management will earn (almost) no profit.

Moreover, the larger institutional clients can replicate a money management business in-house. Such in-house money management would further drive down the profits of money managers. This idea should appeal especially to clients who are skeptical that they can identify money managers who deliver excess returns or that they can identify consultants who can identify such money managers. (But a drawback to managing money in-house is 
that it also requires compensation of in-house money management staff according to the norms common in the money management industry, which may cause considerable friction.)

Institutional money management fees are also probably considerably lower than their retail counterparts, because the costs of asset gathering and account servicing are lower. Comprehensive data on the profitability of institutional money management are not in the public domain, but the ten publicly traded money managers for which profit figures are available manage both mutual funds and institutional money. On average, the mix of assets

is about even and the correlation between revenues/(assets under management) and the fraction of institutional assets is close to zero but positive (indicating that, if anything, for these successful managers, servicing institutional clients is more profitable than servicing retail customers).

In summary, earlier sections of this paper study the pricing implications of the profitability of asset managers. This section stresses the conflict between the profitability and presumed competition in the industry.

\section{Some Perspective}

The work of Ross (2004) on the pricing of clsed-end funds is the closest to the present one. Applying insights from Ross (1978) to an infinitely-lived closed end fund that pays annualy a fraction $d$ of its assets as dividend and charges a fraction $c$ of its assets as fee, his basic result is that the neoclassical theory would price the closed-end fund at a fraction

$$
\frac{d}{d+c}
$$

of net asset value, regardless of the prevailing discount rate. For instance, with $d=3 \%$ and $\mathrm{c}=1 \%$, the shares will be priced at $75 \%$ of net asset value. Thus, Ross applies the no-arbitrage approach to show that the persistent discounts at which closed-end funds trade 
reflect the capitalization of the fees charged by the management companies, and thus are consistent with neo-classical pricing. The present paper takes the very same approach, applies it to other parts of the asset management industry, and points out the tension between the model's implications and observed prices.

Boudukh et al $(2003,2004)$ develop a similar valuation model of the fee charged by asset management firms, with the additional elaboration that the asset flow is sensitive to performance. Moreover, using a panel of mutual funds flows, returns, and other attributes such as age and size, they estimate the model's parameters and use the estimates to calibrate their valuation formula. Naturally, the model itself and the estimation of its parameters and its calibration are all sensitive to the particular functional forms entertained by the authors. Focusing on the revenue side of the money management business, Boudukh et al do not consider the net income of the money managers and therefore do not confront a valuation model with the observed prices of the companies whose main business is money management.

Adhering to a fairly straightforward model, this paper takes a sufficiently different approach that its overlap with the work of Boudukh et al $(2003,2004)$ is minimal. It is tractable, and the relations between the assumptions, the estimators and the insights it provides are transparent. Some of these insights are objectionable in that they seem to contradict conventional wisdom. The objections themselves, however, are likely to have some unpalatable implications. Some of these are mentioned in the paper. Some are left outside it, to keep the discussion focused. In fact, a good metaphor for this paper is that of a blanket too short to cover one's whole body. When it covers one side, the other is left exposed. Similarly, when one tries to settle one issue raised in this paper, another issue comes up.

\section{Concluding Remarks}

The profits of money managers are relatively easy to compute. They are the difference between revenues and expenses, with no need to account for the cost of capital, since little 
capital is tied up in money management. Nonetheless, with low barriers to entry (little capital!) and hundreds of money managers, the industry should be highly competitive. Due to economies of scale in asset management, profits of the larger managers are substantial fractions of their revenues, and they bear no relation to the meager capital that is tied up in the business.

Buy-and-hold, long term investors in mutual funds should be especially attentive to the fees charged by funds. Indeed, one question raised in the present analysis is how actively managed funds can charge fees in the neighborhood of $1 \%$, typically under-perform the relevant index, and retain assets of the same buy-and-hold customers for decades when lowcost index funds are available. Moreover, one implication of this analysis is that sponsors of 401(k) plans should at least make low-cost index funds available to participants in their plans.

The prices of money managers do not seem to reflect the current profitability in the industry. It is possible that the prices anticipate future competition and much lower fees and profits, which is ominous news to current asset managers and to those contemplating entry into the business. It is also possible that the prices of money managers reflect the market's expectations of asset migration away from the traditional money managers.

Neither the popular nor the more narrowly focused media, however, suggest a bleak future for traditional money managers. Hence, a second interpretation of the gap between the theoretical and actual prices of money managers is entertained: those who determine the prices - primarily money managers themselves - misapply the present value formula and excessively discount the very distant future when most of the value should accrue.

The price of an enterprise should reflect expectations of its future cash flows. In general, numerous judgements are made when applying the present value formula to price uncertain cash flows. Because so many free parameters are available in applying the general present value formula, it is next to impossible to confront it with data and to ask to what extent 
market prices actually reflect risk-adjusted present values of expected future cash flows. The task is easier here, because the growth rate of the cash flows from managing money and the relevant discount rates are approximately equal.

The pricing formula discussed here is a special, simple case of the general present value formula. It is valid because, to a first approximation, money managers' earnings grow (or shrink) with the returns on the marketable securities they hold on behalf of their clients. And if the data presented here point out that market prices deviate substantially from the prediction of the pricing formula, then the deviation is also from the general present value formula. One can hardly think of a formula more central to financial economics - indeed, to economics as a whole. 


\section{References}

[1] Boudoukh, Jacob, Matthew Richardson, Richard Stanton and Robert Whitelaw, "Valuing Mutual Fund Companies," NYU Stern Working Paper, 2003.

[2] Boudoukh, Jacob, Matthew Richardson, Richard Stanton and Robert Whitelaw, "The Economics of Asset Management," NYU Stern Working Paper, 2004.

[3] Black, Fischer, "Noise," Journal of Finance, Vol. 41, No. 3 (July 1986) 529-543.

[4] Brennan, Michael J., "Aspects of Insurance, Intermediation and Finance," Invited Lecture to the 1992 Seminar of the European Group of Risk and Insurance Economists, UCLA working paper, 1992.

[5] Cherkes, Martin, "A Positive Theory of Closed-End Funds as an Investment Vehicle," Princeton University Working Paper, July 2004.

[6] Constant, Mark I., "Brokers and Asset Managers, September Quarter Broker/Investment Bank Earnings Preview," Lehman Brothers Report, October 14, 2004.

[7] Goetzmann, William N, Jonathan E. Ingersoll, and Stephen A. Ross, "High Water Marks, and Hedge Fund Management Contracts," Journal of Finance, Vol. 58, pp. 1685-1718, August 2003.

[8] Harrison, Michael and David Kreps, "Speculative Investor Behavior in a Stock Market with Heterogeneous Expectations," Quarterly Journal of Economics 92 (1978), 323-336.

[9] Higgins, Robert C., Analysis for Financial Management, Seventh Edition, McGraw Hill Irwin, 2004.

[10] Investment Company Institute, "Fundamentals," Vol 13, No. 1, February 2004. 
[11] Hopson, Jeff, J., Paul Newsome, Matthew Park, Tim Willi, David Stumpf, David George, and Troy Ward, "Asset Management It's All About Assets," A report by A. G. Edwards, July 16, 2004.

[12] Hopson, Jeff, J., and Greg M. Mason, "SEI Investments," A report by A. G. Edwards, August 10, 2004.

[13] Keynes, John Maynard, "The State of Long-Term Expectations," Chapter 12 in The General Theory of Employment, Interest and Money, 1936; available at www.marxists.org/reference/subject/economics/keynes/general-theory/ch12.htm.

[14] Khorana, Ajay and Henri Servaes, "An Examination of Competition in the Mutual Fund Industry," London Business School working paper, 2003.

[15] Kim, Samuel S., "Mutual Funds: Solving the Shortcomings of The Independent Director Response to Advisory Self-Dealing Through Use of the Undue Influence Standard," Columbia Law Review 98 (1998), 474-509.

[16] Laibson, David I., "Golden Eggs and Hyperbolic Discounting," Quarterly Journal of Economics 62 (1997), 443-478.

[17] Miller, Edward, "Risk, Uncertainty and Divergence of Opinion," Journal of Finance 32 (1977), 1151-1168.

[18] Ross, Stephen A., "A Simple Approach to the Valuation of a Risky Stream," Journal of Business 51 (1978), 453-475.

[19] Ross, Stephen A., "A Neoclassical Look at Behavioral Finance: The Closed End Funds Puzzle," Chapter four of Neoclassical Finance, Princeton University Press 2004.

[20] Scheinkman, Jose A. and Wei Xiong, "Overconfidence and Speculative Bubbles," Journal of Political Economy, 2003. 
[21] Shleifer, Andrei, and Lawrence H. Summers, "The Noise Trader Approach to Finance," Journal of Economic Perspectives 4 (1990) 19-33.

[22] Shleifer, Andrei and Robert Vishny, "The Limits of Arbitrage," Journal of Finance, March, 1997

[23] Sirri, Erik R., and Peter Tufano, "Costly Search and Mutual Fund Flows," Journal of Finance 53 (1998), 1589-1622.

[24] Smith, Adam, The Wealth of Nations: An Inquiry into the Nature and Causes, 1776.

[25] Strotz, R. H., "Myopia and Inconsistency in Dynamic Utility Maximization," Review of Economic Studies 23 (1956), 165-180.

[26] Warther, Vincent A., "Aggregate Mutual Fund Flows and Security Returns," Journal of Financial Economics 39 (1995), 209-235. 